\title{
Morphological and histological changes of celeriac [Apium graveolens L. var. rapaceum (Mill.) Gaud.] as effect of improper use of herbicides
}

\author{
Zmiany morfologiczne i histologiczne selera korzeniowego \\ [Apium graveolens L. var. rapaceum (Mill.) Gaud.] jako efekt \\ nieprawidłowości w stosowaniu herbicydów
}

\author{
Zbigniew Anyszka, Anna Stępowska, Barbara Dyki, Joanna Golian
}

\begin{abstract}
Summary
The studies were conducted in 2010-2011 at the Research Institute of Horticulture in Skierniewice. The aim of the research was to determine the nature and degree of damages and histological changes in celeriac caused by herbicides that are not recommended for application in this crop, such as: bromoxynil, clopyralid, fluroxypyr, MCPA and tribenuron methyl. The herbicides were applied 2-3 weeks after transplanting in the field experiments and in the greenhouse tests at 3-4 leaves stage of celeriac. The herbicides were used at the maximum recommended doses allowed in cultivation of other plant species or reduced to 10 and $2 \%$. Phytotoxicity of herbicides to celeriac was determined during the experiments. The height and biomass of celeriac leaves were measured in the greenhouse tests. Plant material, which had been collected from the experiments, was subjected to macroscopic observation regarding morphological changes of leaves, and microscope evaluation of damages caused to leaf tissues. It has been proved that the examined herbicides can cause damages to celeriac and degree of damages depends on herbicide dose. Clopyralid, fluroxypyr and tribenuron methyl used at the highest doses caused higher crop damages than bromoxynil and MCPA. The symptoms were also observed during histological analysis. High damages of above ground parts of celeriac decreased yields in particular after application of tribenuron methyl and fluroxypyr.
\end{abstract}

Key words: celeriac; herbicide; phytotoxicity; damages; microscopic observation

\begin{abstract}
Streszczenie
W latach 2010-2011, w Instytucie Ogrodnictwa w Skierniewicach prowadzono badania nad określeniem rodzaju i stopnia uszkodzeń roślin selera korzeniowego po zastosowaniu herbicydów, niezalecanych w uprawie tego gatunku. Badano wpływ herbicydów zawierających następujące substancje czynne: bromoksynil, chlopyralid, fluroksypyr, MCPA oraz tribenuron metylowy. W doświadczeniach polowych herbicydy stosowano 2-3 tygodnie po sadzeniu rozsady selera, a w testach szklarniowych w fazie 3-4 liści badanych roślin. Stosowano herbicydy w dawkach maksymalnych, zalecanych dla innych gatunków roślin oraz w dawkach obniżonych do 10 i $2 \%$. Zmiany morfologiczne roślin selera określono na podstawie makroskopowej oceny fitotoksyczności zastosowanych herbicydów i mikroskopowych analiz uszkodzeń tkanek liści. W doświadczeniach szklarniowych notowano też wysokość i świeżą masę części nadziemnych testowanych roślin selera. Wykazano, że badane herbicydy powodują uszkodzenia tkanek roślin selera, a stopień tych uszkodzeń zależy od ilości użytego środka. Chlopyralid, fluroksypyr i tribenuron metylowy, użyte w najwyższych dawkach, powodowały znacznie silniejsze uszkodzenia badanych roślin niż bromoksynil i MCPA. Duże uszkodzenia tkanek części nadziemnych roślin selera wpływały na obniżenie plonów, szczególnie po zastosowaniu tribenuronu metylowego i fluroksypyru.
\end{abstract}

Słowa kluczowe: seler; herbicydy; fitotoksyczność; uszkodzenia; ocena mikroskopowa

\footnotetext{
Instytut Ogrodnictwa

Pracownia Herbologii

Konstytucji 3 Maja 1/3, 96-100 Skierniewice

zbigniew.anyszka@inhort.pl
} 


\section{Wstęp / Introduction}

Stosowanie herbicydów jest powszechną i efektywną metodą ochrony roślin uprawnych przed chwastami, jednak nie są to zabiegi całkowicie obojętne dla środowiska rolniczego (Praczyk i Skrzypczak 2004). Herbicyd stanowi szczególne zagrożenie dla gatunku, w którym nie jest zalecany, a jego uprawa graniczy $\mathrm{z}$ roślinami opryskiwanymi w celu ochrony przed chwastami. Niewłaściwe zastosowanie herbicydów na plantacji, użycie zbyt wysokiej dawki lub wykonanie zabiegu w niesprzyjających warunkach, powodujących znoszenie cieczy użytkowej na sąsiednie uprawy, może wywołać zmiany na roślinach uprawnych lub ich znaczne uszkodzenia (Praczyk 2002). Prowadzi to często do obniżenia plonu, a w przypadku naniesienia dużej ilości cieczy nawet do jego utraty. Na skutek przemieszczania się cieczy użytkowej z terenu opryskiwanego na inne uprawy ilość przenoszonego środka może wynosić około $0,1-0,01 \%$ stosowanej dawki herbicydu (Jakubiak 2005). Rodzaj uszkodzeń na roślinach, powodowanych przez herbicydy, zależy od mechanizmu działania substancji czynnej środka oraz wrażliwości rośliny uprawnej i jej mechanizmów obronnych. Ocena morfologiczna i analiza mikroskopowa uszkodzeń roślin powodowanych przez różne herbicydy mogą być przydatne zarówno przy określaniu zasięgu zniszczenia poszczególnych organów i tkanek roślinnych, jak i w diagnozowaniu źródła uszkodzenia.

Celem badań było określenie rodzaju i stopnia uszkodzeń roślin selera korzeniowego [Apium graveolens L. var. rapaceum (Mill.) Gaud.] z wykorzystaniem metod mikroskopowych, po zastosowaniu herbicydów zawierających takie substancje czynne, jak: bromoksynil, chlopyralid, fluroksypyr, MCPA i tribenuron metylowy.

\section{Materiały i metody / Materials and methods}

W latach 2010-2011, w Instytucie Ogrodnictwa w Skierniewicach prowadzono badania polowe, szklarniowe i laboratoryjne $\mathrm{z}$ zastosowaniem herbicydów w uprawie selera korzeniowego. Doświadczenia polowe przeprowadzono na polu doświadczalnym, na glebie płowej, wytworzonej $\mathrm{z}$ utworów piaskowych na glinie zwałowej (1,3-1,5\% substancji organicznych, $\mathrm{pH} 6,5)$. Zakładano je metodą losowanych bloków, w układzie jednoczynnikowym, w 4 powtórzeniach. Wielkość poletek wynosiła $9 \mathrm{~m}^{2}$. Seler korzeniowy, odmiany Diamant, sadzono 26.05.2010 i 17.05.2011 roku, w rzędy w rozstawie $40 \times 30 \mathrm{~cm}$. Do badań wybierano herbicydy stosowane w różnych gatunkach roślin rolniczych, niezalecane w uprawie selera i stosowano je w następujących dawkach: bromoksynil (Emblem $20 \mathrm{WP}$ ) - $400 \mathrm{~g} / \mathrm{ha}$, chlopyralid (Lontrel $300 \mathrm{SL}$ ) - $120 \mathrm{~g} / \mathrm{ha}$, fluroksypyr (Starane $250 \mathrm{EC}$ ) - $200 \mathrm{~g} / \mathrm{ha}$, MCPA (Agritox $500 \mathrm{SL}$ ) - $750 \mathrm{~g} / \mathrm{ha} \mathrm{i}$ tribenuron metylowy (Granstar 75 WG) - 18,8 g/ha. Bromoksynil jest inhibitorem fotosyntezy, chlopyralid, fluroksypyr i MCPA należą do regulatorów wzrostu, a tribenuron metylowy do inhibitorów biosyntezy aminokwasów (Woźnica 2008). Herbicydy stosowano w maksymalnych dawkach zalecanych w innych uprawach $(100 \%)$ oraz obniżonych do 10 i 2\%. Zabiegi wykonywano 3 tygodnie po posadzeniu rozsady selera, opryskiwaczem poletkowym na sprężone powietrze, zaopatrzonym w rozpylacze płaskostrumieniowe Tee-Jet 8002 VS. Zużywano 220 litrów wody na hektar, przy ciśnieniu roboczym $0,2 \mathrm{MPa}$. W badaniach polowych określano fitotoksyczność herbicydów dla selera w \% (0 - brak uszkodzeń, 100 - rośliny zniszczone) po: $3 ; 7 ; 14 ; 21 ; 28 ; 35 ; 42 ; 49 ; 63 ; 77$ i 91 dniach od zabiegu oraz plon po 134-142 dniach od sadzenia. Wyniki plonów poddano analizie statystycznej w oparciu o program analizy wariancji dla doświadczenia jednoczynnikowego, wykorzystujący test Newmana-Keulsa do oceny różnic między średnimi, przy poziomie istotności 5\%.

Przeprowadzono też testy szklarniowe, w których seler korzeniowy opryskiwano takimi samymi herbicydami i w takich samych dawkach, jak w doświadczeniu polowym. Nasiona wysiewano do doniczek o pojemności 51 , wypełnionych ziemią $\mathrm{z}$ substratem torfowym w proporcjach $3: 1$, w dniach 28.07.2010 i 12.05.2011 roku. Doświadczenia zakładano w 5 powtórzeniach, w każdej doniczce pozostawiono po 5 roślin selera. Opryskiwanie wykonywano 22.09.2010 i 2.07.2011 roku, w fazie 3-4 liści selera. Określano stopień fitotoksyczności po: 2; 5; 7 i 14 dniach od zabiegu oraz wysokość roślin i świeżą masę części nadziemnych, po 14 dniach od opryskiwania.

Z doświadczeń polowych i testów szklarniowych wybierano rośliny selera $\mathrm{z}$ makroskopowo stwierdzanymi zmianami po traktowaniu herbicydami. Po ocenie morfologicznej roślin wykonywano badania mikroskopowe liści roślin kontrolnych i roślin traktowanych herbicydami. Analizowano materiał świeży przy użyciu mikroskopu stereoskopowego Olympus SZX 16 (SM) z programem Cell B do fotografowania i archiwizacji dokumentów. W obserwacjach liści świeżych oceniano ich zabarwienie i strukturę na podstawie fragmentów, wykazujących makroskopowo widoczne zmiany. Analizy mikromorfologii powierzchni liści wykonywano przy wykorzystaniu elektronowego mikroskopu skaningowego Jeol JSM-S1 (SEM). W tym celu fragmenty liści $(10 \times 10 \mathrm{~mm})$ utrwalano w histologicznym utrwalaczu CrAF (kwas chromowy, kwas octowy, formalina 40\%), odwadniano w etanolu i acetonie (Gerlach 1972), suszono w aparacie CPD (Critical Point Drying) przy użyciu $\mathrm{CO}_{2}$, a następnie napylano złotem (Hayat 1976).

\section{Wyniki i dyskusja / Results and discussion}

Badania wykazały zróżnicowaną wrażliwość selera korzeniowego na herbicydy stosowane w innych gatunkach roślin uprawnych, niezalecane $\mathrm{w}$ ochronie selera przed chwastami. Większość $\mathrm{z}$ nich wywoływała silną fitotoksyczność. Rodzaj powodowanych uszkodzeń był zależny od rodzaju środka i wysokości użytej dawki. Najsilniejsze uszkodzenia powodowały herbicydy zawierające chlopyralid, fluroksypyr i tribenuron metylowy zastosowane w najwyższej dawce, a ich objawy utrzymywały się do końca wegetacji selera (rys. 1). Niewielkie uszkodzenia stwierdzono po użyciu MCPA i bromoksynilu. Herbicydy badane w doświadczeniach, w daw- 
kach stanowiących $10 \%$ dawek maksymalnych nie powodowały fitotoksyczności lub wywoływały tylko nieznaczne i przemijające uszkodzenia. Praczyk (niepublikowane) podaje, że zastosowanie herbicydu 2,4-D w ilości stanowiącej $0,001 \%$ zalecanej dawki może spowodować uszkodzenia na roślinach pomidora. Herbicydy zawierające chlopyralid, fluroksypyr i MCPA, wykazujące działanie układowe (Praczyk i Skrzypczak 2004) szybko ograniczały wzrost roślin selera korzeniowego. Efekt działania fluroksypyru widoczny był już w dniu zabiegu, a chlopyralidu i MCPA w dniach następnych (rys. 1, 2). Obserwowano ograniczanie wzrostu, liczne deformacje liści i pędów oraz więdnięcie roślin selera. Pojawiały się chlorotyczne plamy na liściach spowodowane zamieraniem tkanek (rys. 3). Herbicydy $\mathrm{z}$ grupy regulatorów wzrostu działają podobnie jak auksyny, substancje naturalnie wytwarzane przez rośliny, mające wpływ, m.in. na podział komórek, syntezę białek, zaburzenia hormonalne (Praczyk 2002; Woźnica 2008). $\mathrm{W}$ doświadczeniach $\mathrm{z}$ herbicydami należącymi do tej grupy związków największe uszkodzenia roślin selera wywoływał fluroksypyr. Uszkodzenia były tak silne, że prowadziły do zamierania pojedynczych roślin. Seler korzeniowy traktowany tribenuronem metylowym był także uszkadzany, przy czym pierwsze objawy uszkodzeń obserwowano po 7 dniach od zabiegu, a w kolejnych dniach ich nasilenie stopniowo zwiększało się. Poza zahamowaniem wzrostu roślin traktowanych tym herbicydem, na blaszkach liściowych obserwowano chlorozy, przechodzące w nekrozy tkanek. Tribenuron metylowy blokuje biosyntezę aminokwasów, takich jak: leucytyna, izoleucytyna i walina, co $\mathrm{w}$ rezultacie prowadzi do zaburzeń we wzroście i rozwoju roślin (Praczyk 2002). Bromoksynil zaliczany do inhibitorów fotosyntezy, wywoływał przejaśnienia i przebarwienia tkanek liści. Po jego zastosowaniu obserwowano też zasychanie brzegów blaszki liściowej selera, jednak powstałe zmiany nie były silne i w miarę upływu czasu stawały się coraz mniej widoczne.

Analizy wykonywane przy użyciu elektronowego mikroskopu skaningowego i mikroskopu stereoskopowego (rys. 4) pozwoliły wniknąć w strukturę komórkową uszkodzonych fragmentów liści selera widocznych po zastosowanych środkach. Badania wykazały różnego typu deformacje komórek epidermy liści, zniekształcenia nerwów liściowych oraz liczne strąty obecne na analizowanej powierzchni tkanki okrywającej (rys. 4).

Obserwowano jednak znaczne różnice zarówno w wielkości powierzchni uszkodzeń liści, jak i w stopniu destrukcji poszczególnych tkanek między badanymi obiektami. Zmianom struktury komórek powierzchniowych towarzyszyły różnice w zabarwieniu fragmentów liści widoczne między kontrolą, a pozostałymi obiektami. Chlorotyczne odbarwienia, zarówno nerwów, jak i blaszki liściowej, sięgały do głębiej położonych, subepidermalnych tkanek wiązki przewodzącej oraz miękiszu liści i po kilku dniach przechodziły w ciemne nekrozy (rys. 4). Obserwowane zmiany wskazują na fitotoksyczne działanie środków w zastosowanych stężeniach. Wykonywane kilkanaście lat temu badania mikroskopowe roślin cebuli i pora wykazały fitotoksyczne działanie oksyfluorofenu, powszechnie stosowanego w uprawach tych gatunków. Liście roślin chronionych tym herbicydem charakteryzowały się licznymi, intensywnie białymi plamami, które powstawały na skutek głębokich uszkodzeń i zniszczenia chloroplastów tkanki miękiszowej (Dyki i wsp. 1992; Dobrzański i wsp. 2003).

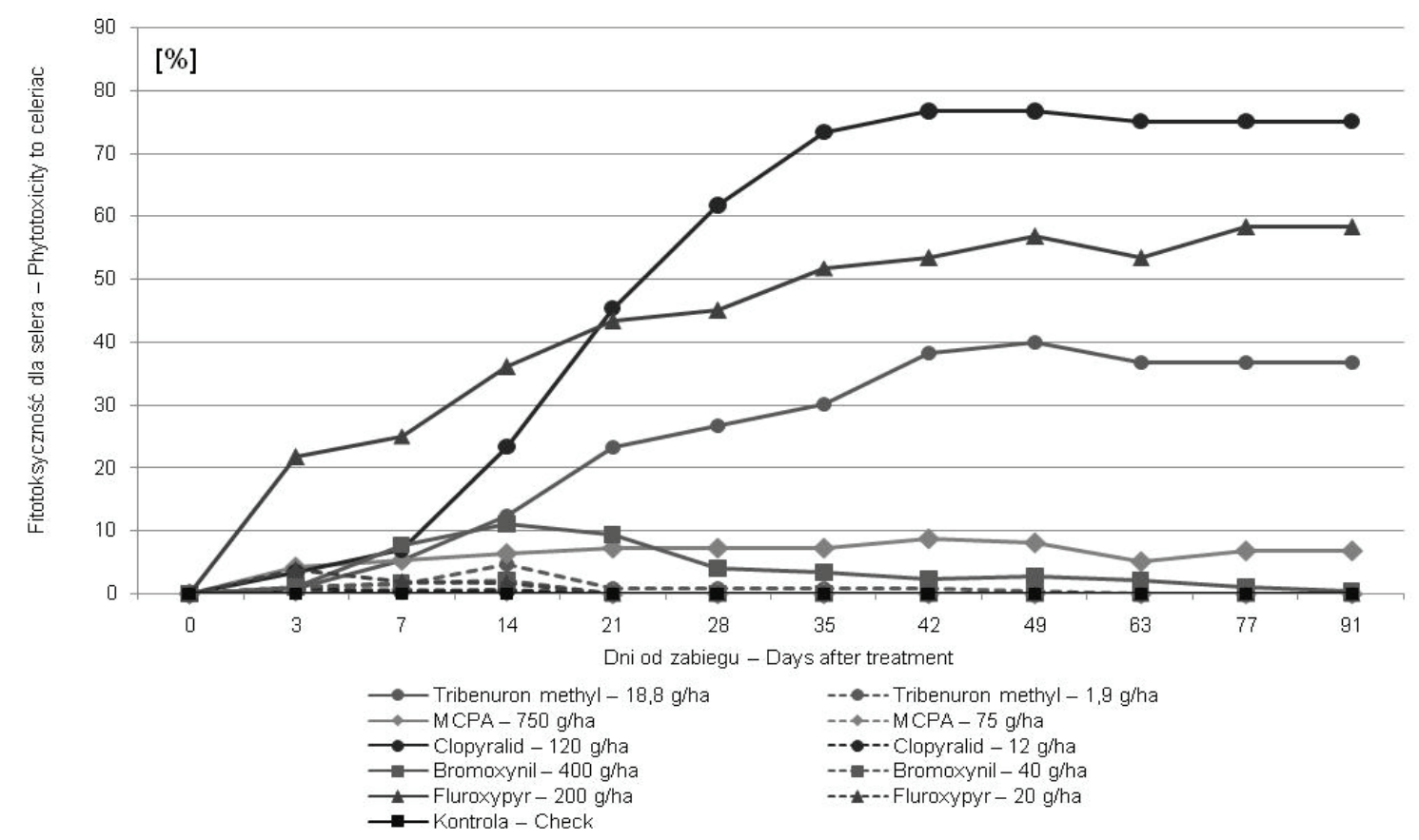

Rys. 1. Fitotoksyczność dla selera korzeniowego herbicydów stosowanych w dawce maksymalnej i obniżonej do 10\% (doświadczenie polowe)

Fig. 1. Phytotoxicity of herbicides at the maximum dose and reduced to 10 percent to celeriac (field experiment) 


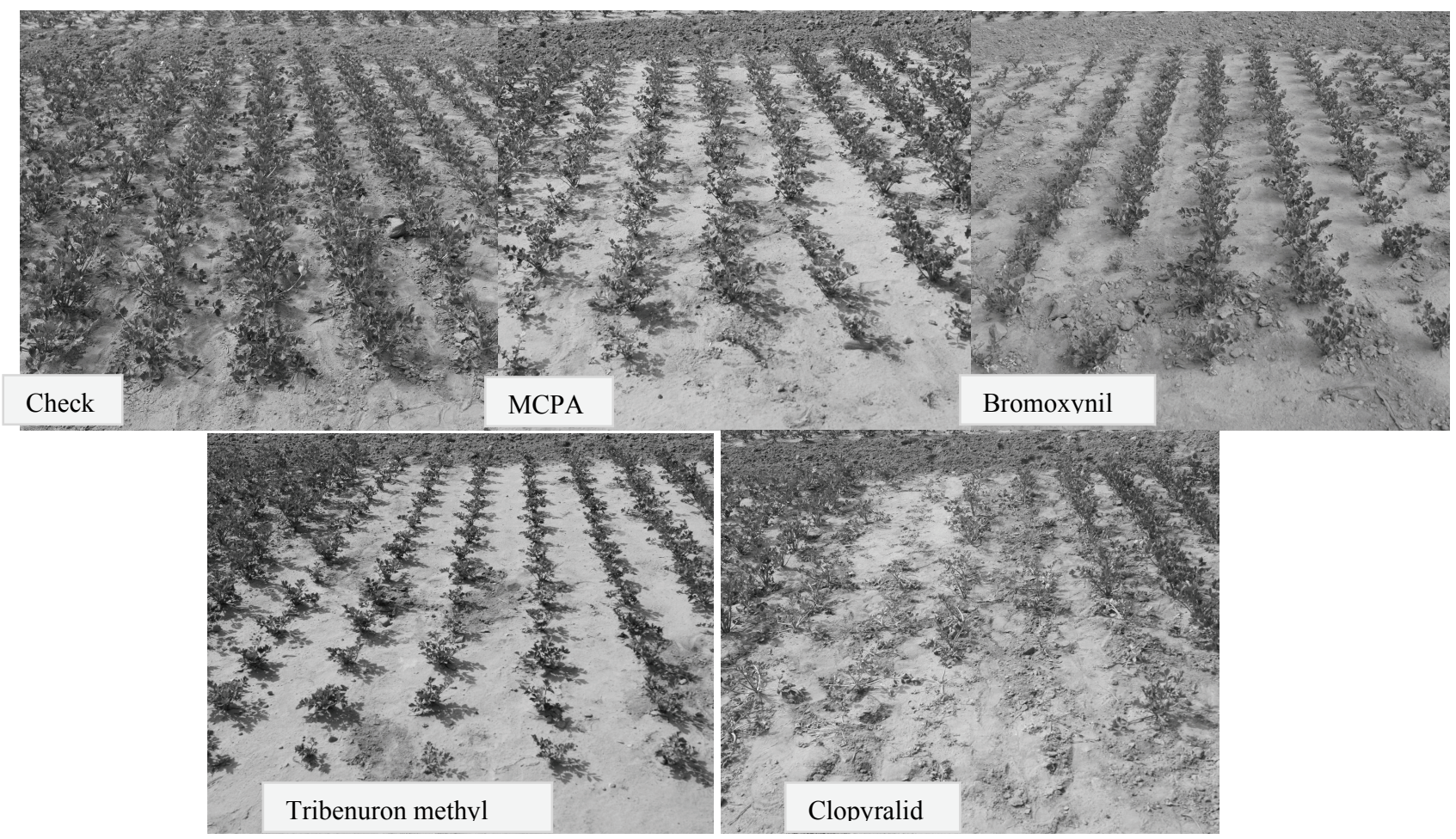

Rys. 2. Efekty uszkodzeń roślin selera korzeniowego w uprawie polowej, wywołane przez herbicydy stosowane w maksymalnej dawce Fig. 2. Damages to celeriac plants grown in the field, caused by maximum dose of herbicides
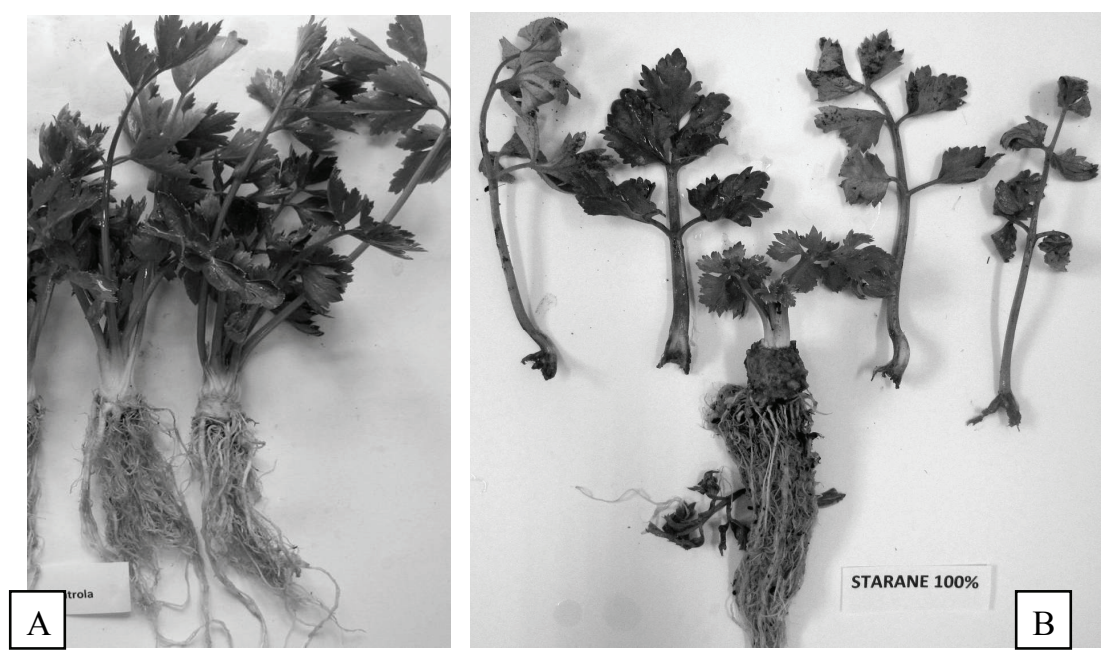

Rys. 3. Wpływ fluroksypyru (B) na morfologię roślin selera korzeniowego (A - kontrola)

Fig. 3. The influence of fluroxypyr (B) on the morphology of celeriac plants (A - check)

Z przeprowadzonych badań mikromorfologii komórek epidermy liści selera wynika, że najmniejsze uszkodzenia tkanki epidermalnej wywoływał bromoksynil, który powodował tylko nieznaczne zmiany w porównaniu $\mathrm{z}$ materiałem kontrolnym (rys. 4). Największe destrukcje w budowie epidermy analizowanych liści, prowadzące do ich zamierania, notowano po użyciu środka fluroksypyr (rys. 4). Podobnie wysoką wrażliwość, objawiającą się degeneracją komórek epidermy i miękiszu liści, zanotowano w mikroskopowych badaniach fasoli chronionej metrybuzyną i linuronem, jednak tkanki roślin pochodzących $\mathrm{z}$ testów szklarniowych wykazywały silniejsze efekty destrukcyjnego działania herbicydów niż u fasoli z uprawy polowej (Dyki i wsp. 2012). Chlopyralid badany w doświadczeniach w uprawie selera nie powodował deformacji komórek, ale pozostawiał strąty na powierzchni epidermy liści, z których znaczna część osadzała się w otworach aparatów szparkowych (rys. 4). Bezpośredni kontakt herbicydu ze strukturami komórkowymi odpowiadającymi za wymianę gazową i proces transpiracji prowadzić może do niekorzystnych dla roślin zmian fizjologicznych, a w rezultacie do nekrozy liści.

Stopień fitotoksyczności badanych środków i powodowane przez nie objawy uszkodzeń, obserwowane w warunkach polowych, potwierdził test szklarniowy, w którym rośliny traktowane były takimi samymi herbicydami 

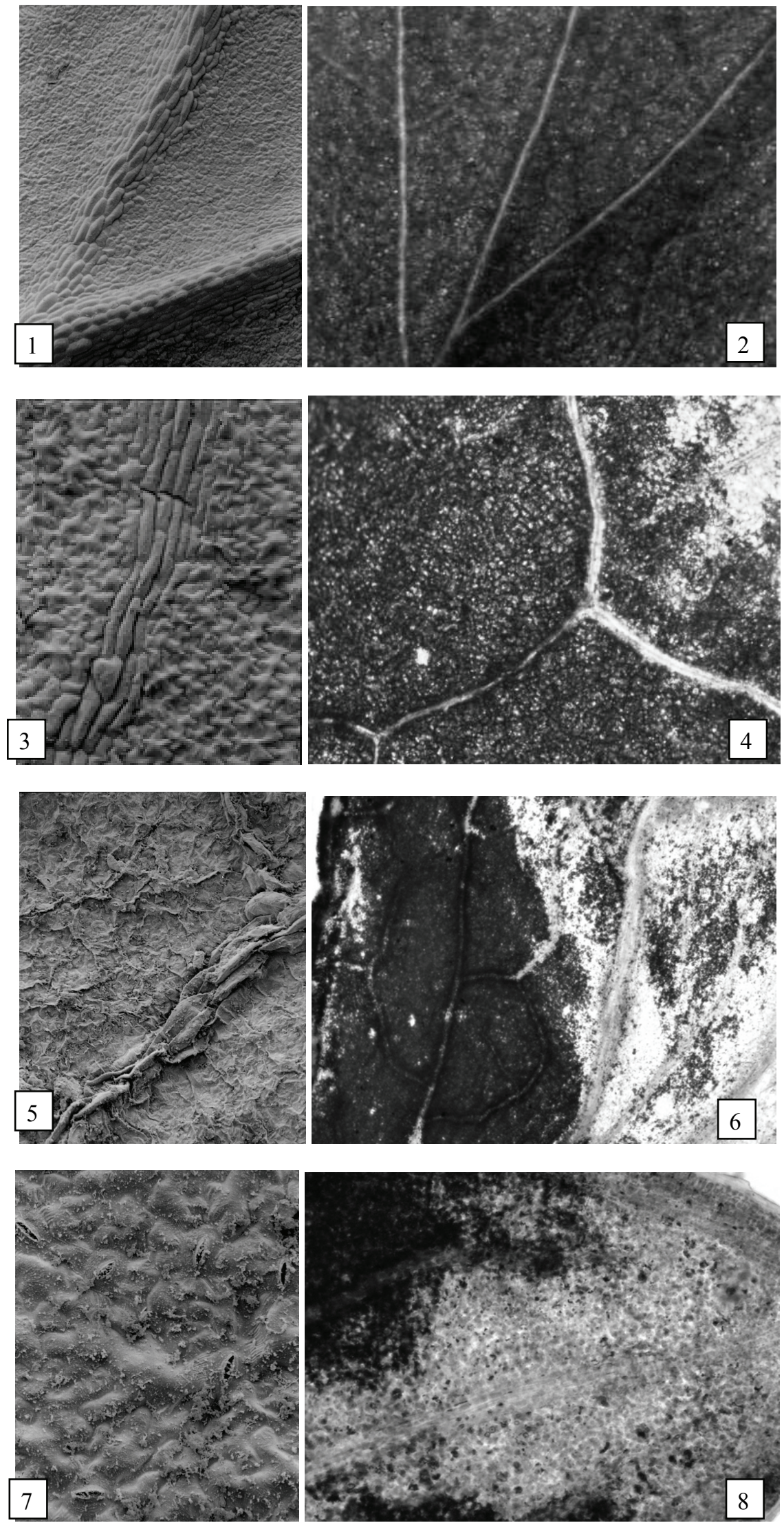

Rys. 4. Wpływ bromoksynilu $(3,4)$, fluroksypyru $(5,6)$ i chlopyralidu $(7,8)$ na strukturę epidermy liści selera korzeniowego (1,2 - kontrola). Elektronowy mikroskop skaningowy (fot. 1, 3, 5, 7); mikroskop stereoskopowy (fot. 2, 4, 6, 8)

Fig. 4. The influence of bromoxynil $(3,4)$, fluroxypyr $(5,6)$ and clopyralid $(7,8)$ on the structure of leaves of celeriac (1, 2 - check). Scanning electron microscope (fig. 1, 3, 5, 7); stereo microscope (fig. 2, 4, 6, 8) 
Tabela 1. Wpływ herbicydów na rośliny selera korzeniowego w teście szklarniowym (średnie z lat 2010-2011)

Table 1. The influence of herbicides on celeriac in greenhouse test (means for 2010-2011)

\begin{tabular}{|c|c|c|c|c|c|c|c|c|c|}
\hline \multirow{2}{*}{$\begin{array}{l}\text { Herbicyd } \\
\text { Herbicide }\end{array}$} & \multirow{2}{*}{$\begin{array}{l}\text { Dawka } \\
\text { Dose } \\
\text { [g/ha] }\end{array}$} & \multicolumn{4}{|c|}{$\begin{array}{c}\text { Fitotoksyczność } \\
\text { Phytotoxicity } \\
{[\%]}\end{array}$} & \multicolumn{2}{|c|}{$\begin{array}{l}\text { Wysokość roślin } \\
\text { Height of plants }\end{array}$} & \multicolumn{2}{|c|}{$\begin{array}{c}\text { Masa roślin } \\
\text { Weight of plants }\end{array}$} \\
\hline & & $2 \mathrm{DAT}^{*}$ & $5 \mathrm{DAT}$ & $7 \mathrm{DAT}$ & $14 \mathrm{DAT}$ & {$[\mathrm{cm}]$} & $\begin{array}{c}\text { redukcja } \\
\text { reduction } \\
{[\%]}\end{array}$ & {$[\mathrm{g}]$} & $\begin{array}{c}\text { redukcja } \\
\text { reduction } \\
{[\%]}\end{array}$ \\
\hline \multirow{3}{*}{ Tribenuron methyl } & 18,8 & 0,4 & 3,5 & 11,8 & 36,7 & 7,1 & 50,3 & 0,91 & 64,7 \\
\hline & 1,88 & 0,2 & 2,5 & 3,1 & 11,2 & 8,5 & 40,6 & 1,28 & 51,7 \\
\hline & 0,38 & 0 & 0 & 0,3 & 3,2 & 10,6 & 25,9 & 1,43 & 46,0 \\
\hline \multirow{3}{*}{ MCPA } & 750 & 23,7 & 46,8 & 61,2 & 71,7 & 6,5 & 54,5 & 1,44 & 45,7 \\
\hline & 75 & 4,2 & 3,5 & 6,1 & 4,2 & 14,7 & 0 & 2,47 & 6,8 \\
\hline & 15 & 0,9 & 1,8 & 1,9 & 1,7 & 14,8 & 0 & 2,42 & 8,7 \\
\hline \multirow{3}{*}{ Clopyralid } & 120 & 18,9 & 57,5 & 70,2 & 80,4 & 6,9 & 51,7 & 1,39 & 47,5 \\
\hline & 12 & 3,8 & 6,8 & 7,9 & 8,2 & 14,3 & 0 & 1,99 & 24,9 \\
\hline & 2,4 & 0,3 & 2,5 & 2,2 & 3,8 & 14,3 & 0 & 2,52 & 4,9 \\
\hline \multirow{3}{*}{ Bromoxynil } & 400 & 1,4 & 18,3 & 76,3 & 93,7 & 3,6 & 74,8 & 0,36 & 86,4 \\
\hline & 40 & 0 & 1,3 & 27,2 & 45,4 & 7,4 & 48,3 & 0,72 & 72,8 \\
\hline & 8 & 0 & 0 & 1,9 & 2,8 & 11,7 & 18,2 & 2,00 & 24,5 \\
\hline \multirow{3}{*}{ Fluroxypyr } & 200 & 23,4 & 56,3 & 64,6 & 77,4 & 7,4 & 48,3 & 1,54 & 41,9 \\
\hline & 20 & 17,3 & 22,5 & 47,4 & 45,9 & 11,1 & 22,4 & 1,82 & 31,3 \\
\hline & 4 & 11,9 & 12,3 & 21,7 & 19,6 & 12,7 & 11,2 & 2,31 & 12,8 \\
\hline Kontrola-Check & - & 0 & 0 & 0 & 0 & 14,3 & 0 & 2,65 & 0 \\
\hline
\end{tabular}

*dni od zabiegu - days after treatment

Tabela 2. Plon ogólny selera korzeniowego, w zależności od rodzaju herbicydu i jego dawki

Table 2. Total yield of celeriac, depending on the type and dose of herbicide

\begin{tabular}{|c|c|c|c|c|c|}
\hline \multirow{3}{*}{$\begin{array}{l}\text { Herbicyd } \\
\text { Herbicide }\end{array}$} & \multirow{3}{*}{$\begin{array}{l}\text { Dawka } \\
\text { Dose } \\
\text { [g/ha] }\end{array}$} & \multicolumn{4}{|c|}{ Plon ogólny - Total Yield } \\
\hline & & \multicolumn{2}{|r|}{2010} & \multicolumn{2}{|r|}{2011} \\
\hline & & {$\left[\mathrm{kg} / 100 \mathrm{~m}^{2}\right]$} & $\begin{array}{c}\text { udział plonu handlowego } \\
\text { share of marketable yield } \\
{[\%]}\end{array}$ & {$\left[\mathrm{kg} / 100 \mathrm{~m}^{2}\right]$} & $\begin{array}{c}\text { udział plonu handlowego } \\
\text { share of marketable yield } \\
{[\%]}\end{array}$ \\
\hline \multirow{3}{*}{ Tribenuron methyl } & 18,8 & $*$ & $*$ & $286,9 \mathrm{~b}$ & 98,5 \\
\hline & 1,88 & $175,7 \mathrm{c}$ & 94,9 & $403,9 \mathrm{a}$ & 99,5 \\
\hline & 0,38 & $226,7 \mathrm{bc}$ & 81,3 & $411,8 \mathrm{a}$ & 98,3 \\
\hline \multirow{3}{*}{ MCPA } & 750 & $*$ & $*$ & $317,7 \mathrm{ab}$ & 99,7 \\
\hline & 75 & $329,6 \mathrm{a}$ & 100 & $431,5 \mathrm{a}$ & 100 \\
\hline & 15 & $271,3 \mathrm{abc}$ & 98,6 & $406,9 \mathrm{a}$ & 99,4 \\
\hline \multirow{3}{*}{ Clopyralid } & 120 & $*$ & $*$ & $339,1 \mathrm{a}$ & 96,7 \\
\hline & 12 & $260,2 \mathrm{abc}$ & 98,9 & $371,0 \mathrm{a}$ & 99,2 \\
\hline & 2,4 & $264,7 a b c$ & 99,7 & $416,0 \mathrm{a}$ & 100 \\
\hline \multirow{3}{*}{ Bromoxynil } & 400 & $*$ & $*$ & $312,7 \mathrm{ab}$ & 99,1 \\
\hline & 40 & $286,7 \mathrm{ab}$ & 97,5 & $449,4 \mathrm{a}$ & 100 \\
\hline & 8 & $215,4 \mathrm{bc}$ & 98,0 & $407,5 \mathrm{a}$ & 99,7 \\
\hline \multirow{3}{*}{ Fluroxypyr } & 200 & $*$ & $*$ & $288,4 \mathrm{~b}$ & 81,6 \\
\hline & 20 & $233,1 \mathrm{abc}$ & 99,3 & $392,0 \mathrm{a}$ & 99,8 \\
\hline & 4 & $228,6 \mathrm{abc}$ & 98,8 & $369,0 \mathrm{a}$ & 100 \\
\hline \multicolumn{2}{|l|}{ Kontrola-Check } & $254,8 \mathrm{abc}$ & 99,6 & $439,4 \mathrm{a}$ & 99,6 \\
\hline
\end{tabular}

*W roku 2010 nie zebrano plonu z poletek, na których stosowano herbicydy w najwyższych dawkach - in 2010 the yield from the plots treated with herbicides at the highest doses was not harvested

Wartości oznaczone tą samą literą nie różnią się istotnie przy $\mathrm{p}=0,05-$ Values followed by the same letter are not significantly different at $\mathrm{p}=0.05$ 
i w takich samych dawkach. Test ten wykazał, że w miarę zwiększania dawki herbicydów, zwiększała się ich fitotoksyczność dla selera, a wysokość roślin i ich masa zmniejszały się (tab. 1).

Najsilniejsze objawy obserwowano na roślinach opryskiwanych tribenuronem metylu. Środek ten nawet w dawce zredukowanej do $2 \%$ dawki zalecanej dla innych gatunków, ograniczał wysokość roślin selera o 25,9\%, a ich masę o 46\%. Podobne zależności obserwowano na roślinach traktowanych bromoksynilem, który stosowany w dawce stanowiącej $2 \%$ pełnej dawki tego środka ograniczał wysokość roślin o $18,2 \%$, a ich masę o $24,5 \%$. W warunkach polowych środek zastosowany w takiej dawce nie powodował widocznych uszkodzeń selera.

$\mathrm{W}$ doświadczeniach polowych $\mathrm{z}$ diagnozowaniem rodzaju i stopnia uszkodzeń, powodowanych przez herbicydy, określano też wysokość plonów korzeni selera, w celu pełniejszej oceny jego wrażliwości. Plony selera traktowanego badanymi herbicydami były zróżnicowane (tab. 2). W 2010 roku istotne ograniczenie wysokości plonu obserwowano pod wpływem tribenuronu metylu, stosowanego $\mathrm{w}$ dawce ograniczonej do $10 \%$ (po zastosowaniu pełnej dawki plonu nie określano). W roku 2011 wszystkie herbicydy stosowne w pełnej dawce oraz chlopyralid w dawce ograniczonej do $10 \%$, wyraźnie zmniejszały plon ogólny selera. Udział plonu handlowego w plonie ogólnym był we wszystkich przypadkach wysoki, niezależnie od ilości środka naniesionego na rośliny selera korzeniowego. Niższe plony w roku 2010 spowodowane były późniejszym terminem sadzenia rozsady i niekorzystnym przebiegiem warunków atmosferycznych w czasie wegetacji.

Reasumując, można stwierdzić, że herbicydy badane w doświadczeniach działały fitotoksycznie na seler korze- niowy, a opisy morfologiczne oraz analizy makro- i mikroskopowe uszkodzonych roślin dają możliwość rozpoznania źródła uszkodzeń roślin warzywnych, powodowanych przez herbicydy niezalecane do odchwaszczania selera korzeniowego.

\section{Wnioski / Conclusions}

1. Herbicydy stosowane w różnych gatunkach roślin uprawnych, niezalecane w selerze korzeniowym, powodowały uszkodzenia tej rośliny, a ich stopień zależał od ilości środka wprowadzonego na roślinę.

2. Seler korzeniowy wykazywał wrażliwość na działanie chlopyralidu, fluroksypyru i tribenuronu metylu, stosowanych w najwyższych dawkach, a objawy uszkodzeń utrzymywały się do końca wegetacji.

3. Uszkodzenia roślin wywołane przez niewłaściwe użycie tribenuronu metylu i fluroksypyru powodowały większe obniżenie plonu selera korzeniowego, niż uszkodzenia wywołane przez chlopyralid i MCPA.

4. W teście szklarniowym wykazano, że zwiększenie dawki środka powodowało zwiększenie stopnia uszkodzeń i zmniejszenie wysokości roślin i ich masy.

Badania prowadzono w ramach Programu Wieloletniego „Rozwój zrównoważonych metod produkcji ogrodniczej w celu zapewnienia wysokiej jakości biologicznej i odżywczej produktów ogrodniczych oraz zachowania bioróżnorodności środowiska i ochrony jego zasobów", realizowanego w Instytucie Ogrodnictwa w Skierniewicach.

\section{Literatura / References}

Dobrzański A., Dyki B., Pałczyński J. 2003. Zmiany morfologiczne i cytologiczne wywołane na warzywach cebulowych przez oksyfluorofen. [Morphological and cytological injuries symptoms on allium crops caused by oxyfluorfen]. Prog. Plant Prot./Post. Ochr. Roślin 43 (1): 102-108.

Dyki B., Anyszka Z., Stępowska A., Golian J. 2012. Histological changes of snap bean (Phaseolus vulgaris L.) caused by herbicides. p. 71-72. In: Proc. 6th Int. Weed Sci. Congress. China, Hangzhou, June 17-22, 2012, 149 pp.

Dyki B., Staniaszek M., Pałczyński J. 1992. Zmiany anatomiczne w liściach cebuli jadalnej i komosy białej wywołane herbicydem Goal 2 E. s. 123-124. W: 5. Ogólnopolska Konf. PTB „Mechanizmy regulacji morfogenezy roślin oraz ich funkcjonowanie w warunkach stresowych i zanieczyszczenia środowiska”. Rogów, 15-16.06.1992, 182 pp.

Gerlach D. 1972. Zarys mikrotechniki botanicznej. PWRiL, Warszawa, 297 ss.

Hayat M.A. (ed.). 1976. Principles and Techniques of Scanning Electron Microscopy, Vol. 5. Van Nostrand Reinhold Co., New York, $242 \mathrm{pp}$.

Jakubiak S. 2005. Znoszenie herbicydów. Ochrona Roślin 2: 21-24.

Praczyk T. 2002. Diagnostyka uszkodzeń herbicydowych roślin rolniczych. PWRiL, Poznań, 144 ss.

Praczyk T., Skrzypczak G. 2004. Herbicydy. PWRiL, Poznań, 274 ss.

Woźnica Z. 2008. Mechanizm działania i charakterystyka herbicydów. s. 167-224. W: „Herbologia. Podstawy biologii, ekologii i zwalczania chwastów" (M. Krupa, red.). PWRiL, Poznań, 430 ss. 